\title{
Optimization of Enhanced Ultrafiltration Conditions for Cd with Mixed Biosurfactants Using the Box-Behnken Response Surface Methodology
}

\author{
Tian Chai ${ }^{1,2}$, Huizhi Yan ${ }^{1}$, Zhibin Zhang ${ }^{3}$, Min Xu ${ }^{4}$, Yicheng $\mathrm{Wu}^{1}{ }^{1}$, Lei Jin ${ }^{1}$, Guohe Huang ${ }^{1,2}$ \\ and Haiyan $\mathrm{Fu}^{1, *}$ \\ 1 Key Laboratory for Environmental Biotechnology of Higher Education of Fujian Province, \\ Xiamen University of Technology, Xiamen 361024, China; chait@xmut.edu.cn (T.C.); \\ yhz0630@126.com (H.Y.); ycwu@xmut.edu.cn (Y.W.); jinl@xmut.edu.cn (L.J.) \\ 2 Faculty of Engineering, University of Regina, 3737 Wascana Parkway, Regina, SK S4S 0A2, Canada; \\ huangg@uregina.ca \\ 3 Xiamen Jinque Testing Technology Co., Ltd, Xiamen 361101, China; zhibin1006@163.com \\ 4 Chinese Academy for Environmental Planning, Beijing 100012, China; xumin@caep.org.cn \\ * Correspondence: fuhy@xmut.edu.cn; Tel.: +86-592-629-1151
}

Received: 28 December 2018; Accepted: 23 February 2019; Published: 28 February 2019

\begin{abstract}
A mixture of the environmentally friendly biosurfactants rhamnolipids and sophorolipids was used as a source of micelles in this study. The Box-Behnken design and response surface methodology was used to investigate the influence of factors on micellar-enhanced ultrafiltration (MEUF). Simulated $\mathrm{Cd}$-containing wastewater was used for testing. Based on single-factor experiments, the initial $\mathrm{Cd}^{2+}$ concentration, biosurfactant mixing ratio $(\alpha)$ and $\mathrm{pH}$ were chosen as influential variables, and both the $\mathrm{Cd}^{2+}$ rejection coefficient and permeation flux were used as responses. A predictive model based on a quadratic polynomial regression equation was established to determine the optimized enhanced ultrafiltration conditions for $\mathrm{Cd}$. The results show that the regression equation is extremely significant and fits the data accurately. The optimal enhanced ultrafiltration conditions are as follows: initial $\mathrm{Cd}^{2+}$ concentration of $10.0 \mathrm{mg} / \mathrm{L}, \alpha$ of 0.30 and $\mathrm{pH}$ of 9.58 . Under these conditions, the rejection coefficient and the permeation flux of $\mathrm{Cd}^{2+}$ are $99.14 \%$ and $37.36 \mathrm{~L} / \mathrm{m}^{2} \cdot \mathrm{h}$, respectively. The experimental results confirm that the experimental values agree well with the values predicted by the model. Further, these results provide theoretical support for using MEUF to treat heavy metal-containing wastewater when biosurfactants are used for micelle formation.
\end{abstract}

Keywords: micellar-enhanced ultrafiltration; Box-Behnken response surface methodology; cadmium; wastewater; optimization

\section{Introduction}

With increasing industrialization, cadmium (Cd) has become widely used in various fields, including mining, metal working, electroplating and paint manufacturing [1]. As a persistent pollutant, Cd persists for a very long time after entering water bodies [2,3]. Cd also harms human health through accumulation in food chains $[4,5]$. The common treatment methods for heavy metal ions in aqueous solutions include adsorption [6-9], bio-based methods [10-12], membrane separation techniques [13-15], electrolysis [16,17] and chemical precipitation [12,18]. Among these, micellar-enhanced ultrafiltration (MEUF), one of the membrane separation techniques, has received recent attention because it has the advantages of low energy consumption, easy operation, high permeation flux and high removal efficiency [1]. This technique removes heavy metal ions by adding surfactants to wastewater to form micelles that heavy metal ions in water adsorb or bind to, and thus 
are retained by ultrafiltration membranes. The performance of the MEUF process may be influenced by some dominant factors including surfactant concentration, $\mathrm{pH}$ of solution and operating pressure of the process [19]. Currently, the surfactants used in MEUF are generally chemical in nature [20-22]. However, chemical surfactants have the shortcomings of high critical micelle concentrations (CMCs), the need to use large amounts for functionality and a high possibility of introducing secondary pollution, which restrict the promotion and application of MEUF. Although biosurfactants feature low CMCs and no secondary pollution, there are very few studies of their application in MEUF [23,24]. Therefore, this work uses a mixture of the environmentally friendly biosurfactants rhamnolipids and sophorolipids as a source of micelles and investigates their effect on the ultrafiltration of $\mathrm{Cd}$. In addition, the Box-Behnken response surface is used to optimize the ultrafiltration conditions with the aim of providing theoretical support for using MEUF to treat heavy metal-containing wastewater when rhamnolipids and sophorolipids are used for micelle formation.

\section{Materials and Methods}

\subsection{Experimental Setup}

The experimental setup is shown in Figure 1. This includes a membrane pump, a pipeline, a pressure gauge and an ultrafiltration membrane. The equipment's technical parameters and the main performance parameters of the ultrafiltration membrane are shown in Tables 1 and 2, respectively.

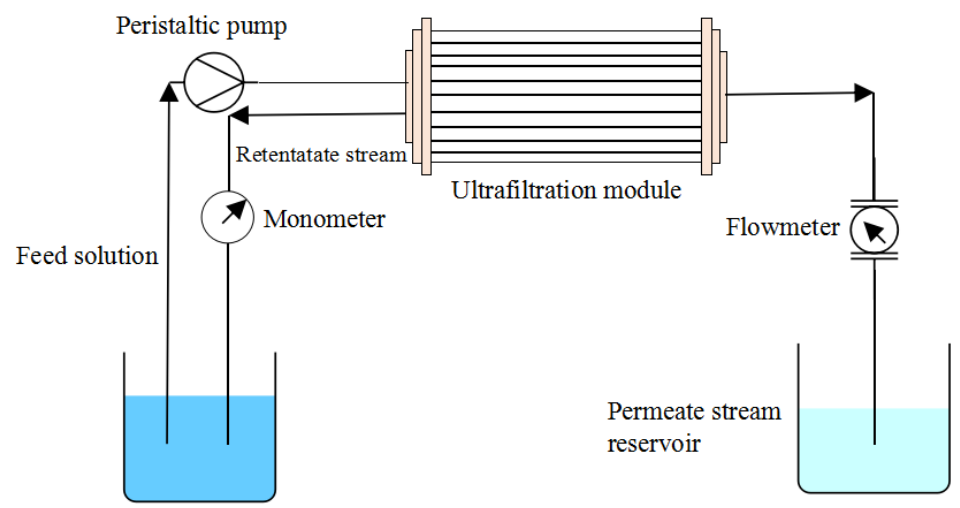

Figure 1. Diagram of the experimental setup.

Table 1. Technical parameters of the equipment.

\begin{tabular}{ccccccc}
\hline $\begin{array}{c}\text { Size of Main } \\
\text { Engine } \mathbf{( c m )}\end{array}$ & $\begin{array}{c}\text { Membrane } \\
\text { Area }\left(\mathbf{c m}^{2}\right)\end{array}$ & $\begin{array}{c}\text { Power } \\
(\mathbf{K w})\end{array}$ & $\begin{array}{c}\text { Minimum } \\
\text { Circulating } \\
\text { Volume }(\mathbf{m L})\end{array}$ & $\begin{array}{c}\text { Working } \\
\text { Pressure } \\
\mathbf{( M P a})\end{array}$ & $\begin{array}{c}\text { Filtration } \\
\text { Capacity (L/h) }\end{array}$ & $\begin{array}{c}\text { Applicable } \\
\text { Temperature } \\
\left({ }^{\circ} \mathbf{C}\right)\end{array}$ \\
\hline $23 \times 27 \times 30$ & 150 & 0.06 & 80 & $\leq 0.5$ & $0.3-3$ & $5-50$ \\
\hline
\end{tabular}

Table 2. Main performance parameters of the ultrafiltration membrane.

\begin{tabular}{cccccc}
\hline $\begin{array}{c}\text { Membrane } \\
\text { Type }\end{array}$ & $\begin{array}{c}\text { Membrane } \\
\text { Material }\end{array}$ & $\begin{array}{c}\text { Molecular Weight } \\
\text { Cutoff (Dalton) }\end{array}$ & $\begin{array}{c}\text { Permeation } \\
\text { Flux }\left(\mathrm{L} / \mathbf{m}^{2} \cdot \mathbf{h}\right)\end{array}$ & $\begin{array}{c}\text { Membrane } \\
\text { Area }\left(\mathrm{cm}^{2}\right)\end{array}$ & $\mathbf{p H}$ \\
\hline SMU-420 & PVDF & 10,000 & $24-53$ & 150 & $2-12$ \\
\hline
\end{tabular}

\subsection{Experimental Methods}

Specified amounts of the biosurfactants, rhamnolipids and sophorolipids were weighed and added to simulated Cd-containing wastewater. After stirring with a magnetic stirrer on a hot plate, the solution was left standing for $20 \mathrm{~min}$ and then ultrafiltered. The simulated wastewater entered the membrane assembly through the membrane pump. The concentrated solution flowed back to the feed 
chute for ultrafiltration, and the filtrate was collected in a special container to measure the permeation flux. An appropriate amount of filtrate was collected to measure the Cd concentration.

\subsection{Box-Behnken Response Curve Design}

Box-Behnken designs have served as a popular choice for second-order models, and have been widely used in completely randomized experiments, split-plot experiments and within the robust parameter design setting [25]. By choosing three different levels of the initial $\mathrm{Cd}^{2+}$ concentration, the mixing ratio of biosurfactants ( $\alpha$ : the ratio of the sophorolipid concentration to the total surfactant concentration) and $\mathrm{pH}$ and using the rejection coefficient and permeation flux of $\mathrm{Cd}^{2+}$ as the two indexes, Minitab 16 was used to design the Box-Behnken response curve experiments. The three different levels of influential variables are shown in Table 3.

Table 3. Independent variables, levels and symbols for the Box-Behnken design.

\begin{tabular}{ccccc}
\hline \multirow{2}{*}{ Variable } & \multirow{2}{*}{ Symbol } & \multicolumn{3}{c}{ Variable Levels } \\
\cline { 3 - 5 } & & Low (-1) & Middle (0) & High (+1) \\
\hline $\mathrm{Cd}^{2+}$ Concentration $(\mathrm{mg} / \mathrm{L})$ & $\mathrm{A}$ & 10 & 25 & 40 \\
$\alpha$ & $\mathrm{B}$ & 0.05 & 0.175 & 0.3 \\
$\mathrm{pH}$ & $\mathrm{C}$ & 4 & 7 & 10 \\
\hline
\end{tabular}

\subsection{Sample Measurements and Calculation}

1. The $\mathrm{Cd}^{2+}$ concentration of the wastewater was measured using an inductively coupled plasma optical emission spectrometer (PE ICP-OES Optima 7000DV).

2. The rejection coefficient was calculated using the following equation:

$$
\mathrm{R}=1-\frac{\mathrm{C}_{\mathrm{p}}}{\mathrm{C}_{\mathrm{f}}}
$$

where $C_{p}$ is the concentration of pollutants in the filtrate $(\mathrm{mg} / \mathrm{L}), \mathrm{C}_{\mathrm{f}}$ is the concentration of pollutants in the feed solution $(\mathrm{mg} / \mathrm{L})$, and $\mathrm{R}$ is the rejection coefficient for the pollutants.

3. The permeation flux was calculated using the following equation:

$$
\mathrm{J}=\frac{\mathrm{Q}}{\mathrm{A} \Delta \mathrm{t}^{\prime}}
$$

where $\mathrm{Q}$ is the volume of filtrate $(\mathrm{L}), \Delta \mathrm{t}$ is the running time $(\mathrm{h}), \mathrm{A}$ is the area of the ultrafiltration membrane $\left(\mathrm{m}^{2}\right)$, and $\mathrm{J}$ is the permeation flux $\left(\mathrm{L} / \mathrm{m}^{2} \cdot \mathrm{h}\right)$.

\section{Results and Analysis}

\subsection{Analysis of the $\mathrm{Cd}^{2+}$ Rejection Coefficient}

The experiments were conducted according to the Box-Behnken response surface design. The experimental and predicted values of the $\mathrm{Cd}^{2+}$ rejection coefficient $\left(\mathrm{R}_{\mathrm{Cd}}\right)$ are shown in Table 4 . Table 4 shows that the maximum experimental value of the $\mathrm{Cd}^{2+}$ rejection coefficient was $99.8 \%$, which is close to the predicted value, indicating that the design of the Box-Behnken response surface is reasonable and scientific.

Minitab 16 was used to fit the experimental values of the $\mathrm{Cd}^{2+}$ rejection coefficient to obtain a complete quadratic regression model for the relationship among the $\mathrm{Cd}^{2+}$ rejection coefficient $\left(\mathrm{R}_{\mathrm{Cd}}\right)$ and the initial $\mathrm{Cd}^{2+}$ concentration, the biosurfactant mixing ratio $(\alpha)$ and the $\mathrm{pH}$, that is,

$$
\begin{gathered}
R_{C d}=-63.730-0.962 A+23.920 B+40.062 C-0.013 A^{2}-124.533 B^{2}-2.422 C^{2}+0.520 A \times B+ \\
0.139 A \times C+0.467 B \times C
\end{gathered}
$$


The regression equation shows that the $\mathrm{Cd}^{2+}$ concentration had a negative effect on the $\mathrm{Cd}^{2+}$ rejection coefficient, while $\alpha$ and $\mathrm{pH}$ had positive effects on the $\mathrm{Cd}^{2+}$ rejection coefficient. These results indicate that the larger $\alpha$ and the $\mathrm{pH}$ are, the better the effect on the $\mathrm{Cd}^{2+}$ rejection coefficient is, and the greater the $\mathrm{Cd}^{2+}$ concentration is, the worse the effect on the $\mathrm{Cd}^{2+}$ rejection coefficient is.

Table 4. Experimental and predicted values of the $\mathrm{Cd}^{2+}$ rejection coefficient.

\begin{tabular}{ccccccc}
\hline Std & Run & \multicolumn{3}{c}{ Factor } & \multicolumn{1}{c}{$\begin{array}{c}\text { Experimental Cd } \mathbf{C d}^{2+} \\
\text { Rejection Coefficient (\%) }\end{array}$} & $\begin{array}{c}\text { Predicted Cd }^{2+} \\
\text { Rejection Coefficient (\%) }\end{array}$ \\
\cline { 3 - 6 } & & $\mathbf{A}$ & $\mathbf{B}$ & $\mathbf{C}$ & 99.7 & 98.2 \\
1 & 15 & -1 & -1 & 0 & 76.2 & 80.1 \\
2 & 2 & 1 & -1 & 0 & 99.3 & 95.4 \\
3 & 5 & -1 & 1 & 0 & 79.7 & 81.2 \\
4 & 4 & 1 & 1 & 0 & 50.5 & 25.1 \\
5 & 3 & -1 & 0 & -1 & 27.2 & 99.9 \\
6 & 7 & 1 & 0 & -1 & 98.0 & 96.3 \\
7 & 12 & -1 & 0 & 1 & 99.8 & 41.3 \\
8 & 8 & 1 & 0 & 1 & 43.3 & 40.1 \\
9 & 9 & 0 & -1 & -1 & 39.7 & 99.3 \\
10 & 11 & 0 & 1 & -1 & 99.6 & 98.8 \\
11 & 6 & 0 & -1 & 1 & 96.7 & 93.6 \\
12 & 1 & 0 & 1 & 1 & 94.1 & 93.6 \\
13 & 10 & 0 & 0 & 0 & 94.4 & \\
14 & 14 & 0 & 0 & 0 & 92.2 & \\
15 & 13 & 0 & 0 & 0 & & \\
\hline
\end{tabular}

Various statistical parameters are presented in Table 5 for analysis of the results related to the $\mathrm{Cd}^{2+}$ rejection coefficient. The $\mathrm{F}$ values in Table 5 show that the factors' impacts on $\mathrm{R}_{\mathrm{Cd}}$ are in the following order: $\alpha<\mathrm{Cd}^{2+}$ concentration $<\mathrm{pH}$. The $\mathrm{P}$ value is the probability value used to specify the statistically significant effects in the model. The $P$ values of each item in Table 5 show that the effect of the $\mathrm{pH}$ on $\mathrm{R}_{\mathrm{Cd}}$ is extremely significant, whereas the effects of the $\mathrm{Cd}^{2+}$ concentration and $\alpha$ on $\mathrm{R}_{\mathrm{Cd}}$ are insignificant, and the effect of the interaction between the $\mathrm{Cd}^{2+}$ concentration and the $\mathrm{pH}$ on $\mathrm{R}_{\mathrm{Cd}}$ (AC) is significant. The similar rule has been observed in previous experiments on mono-rhamnolipid micelles using MEUF [24].

Table 5. Tests of response function $\mathrm{R}_{\mathrm{Cd}}$.

\begin{tabular}{ccccccc}
\hline Source & df & SS & MS & F-Value & $P$ & Significant \\
\hline Model & 9 & 9253.67 & 1028.19 & 65.52 & $<0.001$ & $* *$ \\
Linear & 3 & 7332.54 & 768.63 & 48.98 & $<0.001$ & $* *$ \\
Square & 3 & 1759.71 & 586.57 & 37.38 & 0.001 & $* *$ \\
Interaction & 3 & 161.43 & 53.81 & 3.43 & 0.109 & \\
A & 1 & 521.64 & 41.76 & 2.66 & 0.164 & \\
B & 1 & 1.44 & 2.08 & 0.13 & 0.731 & \\
C & 1 & 6809.45 & 2004.08 & 127.7 & 0.000 & $*$ \\
$\mathrm{~A}^{2}$ & 1 & 5.38 & 30.96 & 1.97 & 0.219 & \\
$\mathrm{~B}^{2}$ & 1 & 0.27 & 13.98 & 0.89 & 0.389 & $*$ \\
$\mathrm{C}^{2}$ & 1 & 1754.06 & 1754.06 & 111.77 & $<0.001$ & $*$ \\
$\mathrm{AB}$ & 1 & 3.80 & 3.80 & 0.24 & 0.643 & $*$ \\
AC & 1 & 157.50 & 157.50 & 10.04 & 0.025 & \\
BC & 1 & 0.12 & 0.12 & 0.01 & 0.933 & \\
Residual & 5 & 78.47 & 15.69 & & & \\
Lack of fit & 3 & 75.62 & 25.21 & 17.71 & 0.054 & \\
Pure error & 2 & 2.85 & 1.42 & & & \\
Cor total & 14 & 9332.14 & & & & \\
$\mathrm{R}^{2}=0.992$ & & & & & & \\
\hline
\end{tabular}

Note: $P<0.05$ indicates that this item is significant and is denoted by "**, $P<0.01$ indicates that the item is extremely significant and is denoted by "**". A is the $\mathrm{Cd}^{2+}$ concentration; $\mathrm{B}$ is the ratio of the sophorolipid concentration to the total surfactant concentration $(\alpha)$; $\mathrm{C}$ is the $\mathrm{pH}$; $\mathrm{AC}$ represents the interaction of the $\mathrm{Cd}^{2+}$ concentration $(\mathrm{A})$ and the $\mathrm{pH}(\mathrm{B})$, and $\mathrm{AB}$ and $\mathrm{BC}$ are similarly defined; $\mathrm{A}^{2}$ is the quadratic term of the $\mathrm{Cd}^{2+}$ concentration $(\mathrm{A})$, and $\mathrm{B}^{2}$ and $\mathrm{C}^{2}$ are similarly defined. 
Using the quadratic regression model, surface and isoline plots (Figures 2-4) can be drawn to investigate the effects of the three factors $(A, B$ and $C)$ and their interactions $(A B, A C$ and $B C)$ on the $\mathrm{Cd}^{2+}$ rejection coefficient.

Figure 2 shows that the interaction of the $\mathrm{Cd}^{2+}$ concentration and $\alpha$ is insignificant when the $\mathrm{pH}$ is 7; $\alpha$ has a smaller effect on $R_{C d}$ than the $\mathrm{Cd}^{2+}$ concentration does; and $\mathrm{R}_{\mathrm{Cd}}$ decreases as the $\mathrm{Cd}^{2+}$ concentration increases. Figure 3 shows that the interaction of the $\mathrm{Cd}^{2+}$ concentration and the $\mathrm{pH}(\mathrm{AC})$ is significant when $\alpha$ is held at 0.175 , and the optimum point is a $\mathrm{Cd}^{2+}$ concentration of approximately $13.2 \mathrm{mg} / \mathrm{L}$ at a $\mathrm{pH}$ of 8.7 , where the $\mathrm{Cd}^{2+}$ rejection coefficient exceeds $98 \%$. Figure 4 shows that the interaction of $\alpha$ and the $\mathrm{pH}(\mathrm{BC})$ is insignificant when the $\mathrm{Cd}^{2+}$ concentration is held at $25 \mathrm{mg} / \mathrm{L}$; the $\mathrm{pH}$ has a greater effect on the $\mathrm{Cd}^{2+}$ rejection coefficient than $\alpha$, and the $\mathrm{Cd}^{2+}$ rejection coefficient increases with the $\mathrm{pH}$.

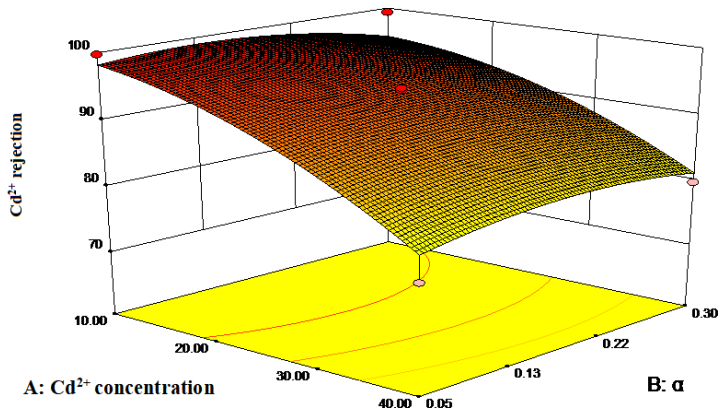

(a)

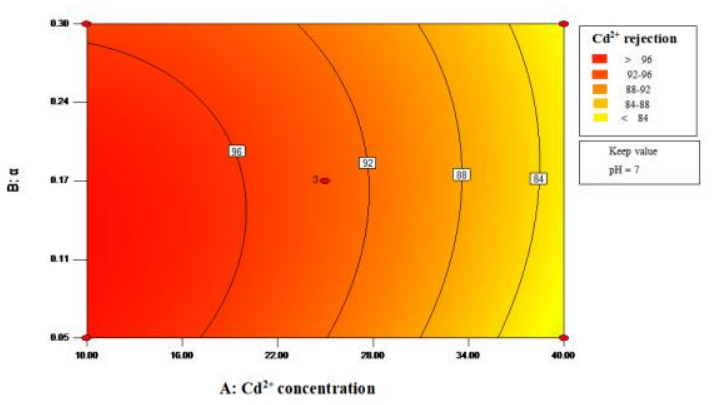

(b)

Figure 2. Response surface (a) and isolines (b) for the $\mathrm{Cd}^{2+}$ rejection rate, the $\mathrm{Cd}^{2+}$ concentration and $\alpha$.

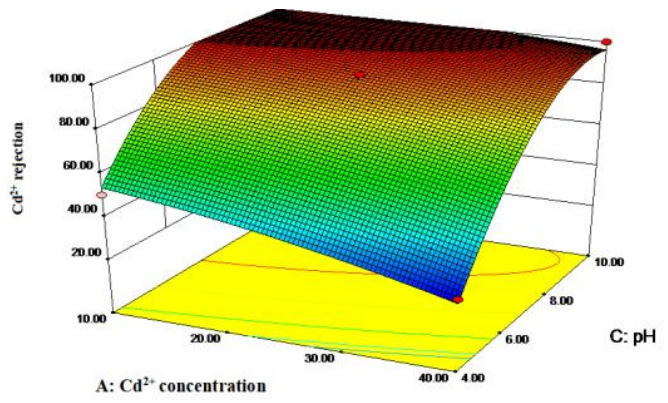

(a)

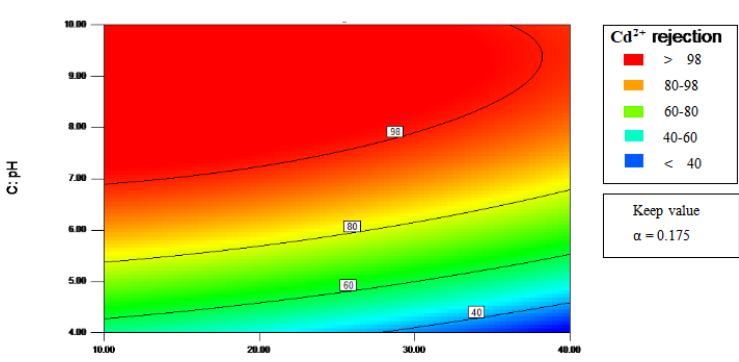

A: $\mathrm{Cd}^{2+}$ concentration

(b)

Figure 3. Response surface (a) and isolines (b) for the $\mathrm{Cd}^{2+}$ rejection rate, the $\mathrm{Cd}^{2+}$ concentration and the $\mathrm{pH}$.

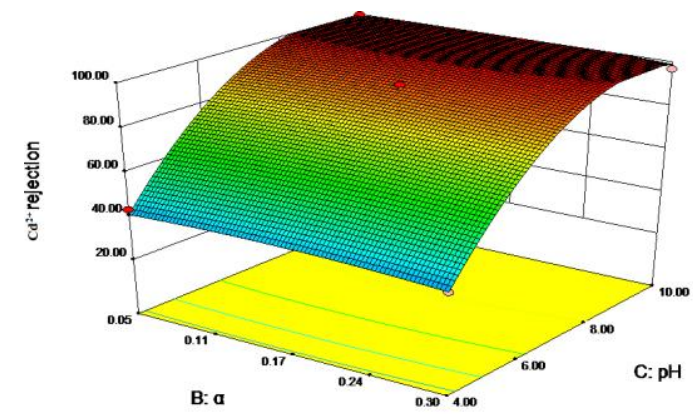

(a)

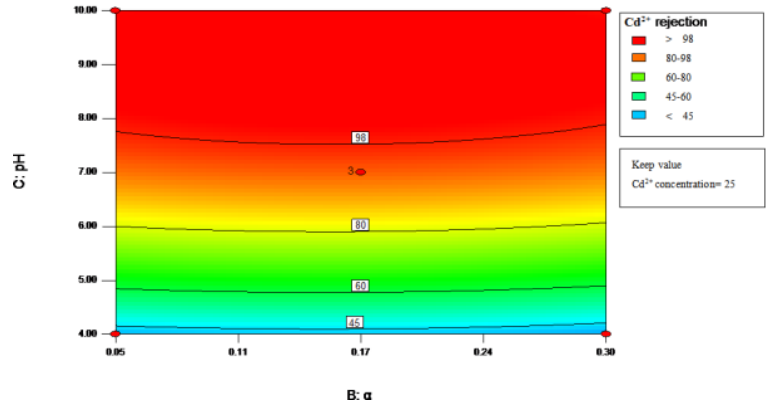

(b)

Figure 4. Response surface (a) and isolines (b) for the $\mathrm{Cd}^{2+}$ rejection rate, $\alpha$ and the $\mathrm{pH}$. 


\subsection{Analysis of Permeation Flux}

The experiments were conducted according to the Box-Behnken design (the response surface design). The experimental and predicted values of the permeation flux (J) are shown in Table 6.

Table 6. Experimental and predicted values of the permeation flux.

\begin{tabular}{|c|c|c|c|c|c|c|}
\hline \multirow{2}{*}{ Std } & \multirow{2}{*}{ Run } & \multicolumn{3}{|c|}{ Factor } & \multirow{2}{*}{$\begin{array}{l}\text { Experimental Values of } \\
\text { Permeation Flux }\left(\mathrm{L} / \mathrm{m}^{2} \cdot \mathrm{h}\right)\end{array}$} & \multirow{2}{*}{$\begin{array}{c}\text { Predicted Values of } \\
\text { Permeation Flux }\left(\mathrm{L} / \mathrm{m}^{2} \cdot \mathrm{h}\right)\end{array}$} \\
\hline & & A & B & $C$ & & \\
\hline 1 & 15 & -1 & -1 & 0 & 19.4 & 19.5 \\
\hline 2 & 2 & 1 & -1 & 0 & 21.3 & 21.0 \\
\hline 3 & 5 & -1 & 1 & 0 & 26.9 & 27.2 \\
\hline 4 & 4 & 1 & 1 & 0 & 20.4 & 20.3 \\
\hline 5 & 3 & -1 & 0 & -1 & 4.4 & 3.3 \\
\hline 6 & 7 & 1 & 0 & -1 & 3.5 & 2.9 \\
\hline 7 & 12 & -1 & 0 & 1 & 28.4 & 29.0 \\
\hline 8 & 8 & 1 & 0 & 1 & 22.9 & 24.0 \\
\hline 9 & 9 & 0 & -1 & -1 & 3.3 & 4.3 \\
\hline 10 & 11 & 0 & 1 & -1 & 3.8 & 4.5 \\
\hline 11 & 6 & 0 & -1 & 1 & 25.1 & 24.4 \\
\hline 12 & 1 & 0 & 1 & 1 & 32.1 & 31.2 \\
\hline 13 & 10 & 0 & 0 & 0 & 15.5 & 15.1 \\
\hline 14 & 14 & 0 & 0 & 0 & 14.9 & 15.1 \\
\hline 15 & 13 & 0 & 0 & 0 & 14.9 & 15.1 \\
\hline
\end{tabular}

Minitab 16 was used to fit a quadratic regression model for the relationship among the permeation flux $(\mathrm{J})$, the $\mathrm{Cd}^{2+}$ concentration, $\alpha$ and the $\mathrm{pH}$ to the experimental values of the permeation flux,

$$
\begin{gathered}
\mathrm{J}=-17.532-0.342 \mathrm{~A}-79.793 \mathrm{~B}+8.618 \mathrm{C}+0.012 \mathrm{~A}^{2}+261.600 \mathrm{~B}^{2}-0.346 \mathrm{C}^{2}-1.120 \mathrm{~A} \times \mathrm{B}- \\
0.026 \mathrm{~A} \times \mathrm{C}+4.333 \mathrm{~B} \times \mathrm{C}
\end{gathered}
$$

The regression equation shows that the $\mathrm{Cd}^{2+}$ concentration and $\alpha$ had a negative effect on the permeation flux $(\mathrm{J})$, while the $\mathrm{pH}$ had a positive effect on J. The results indicate that the higher the $\mathrm{pH}$ is, the higher the membrane flux is; the larger the $\mathrm{Cd}^{2+}$ concentration and $\alpha$ are, the smaller the membrane flux is.

According to the $\mathrm{F}$ values in Table 7 , the factors' impacts on the permeation flux are in the following order: $\mathrm{Cd}^{2+}$ concentration $<\alpha<\mathrm{pH}$. In addition, the $\mathrm{P}$ values in Table 8 show that the effects of $\alpha$ and the $\mathrm{pH}$ on J are extremely significant; the effect of the $\mathrm{Cd}^{2+}$ concentration on J is insignificant; that the effects of the quadratic terms $\left(\mathrm{A}^{2}, \mathrm{~B}^{2}\right.$ and $\left.\mathrm{C}^{2}\right)$ of the $\mathrm{Cd}^{2+}$ concentration $\alpha$ and the $\mathrm{pH}$ on $\mathrm{J}$ are extremely significant and that the effects of the interactions between the $\mathrm{Cd}^{2+}$ concentration and $\alpha$ $(\mathrm{AB})$, and between $\alpha$ and the $\mathrm{pH}(\mathrm{BC})$, on J are very significant.

Using the quadratic regression model, the surface and isolines (Figures 5-7) can be drawn to investigate the effects of the three factors and their interactions on the permeation flux.

Figure 5 shows that the interaction between the $\mathrm{Cd}^{2+}$ concentration and $\alpha(\mathrm{AB})$ is significant when the $\mathrm{pH}$ is kept at 7; when the $\mathrm{Cd}^{2+}$ concentration is $10-19.5 \mathrm{mg} / \mathrm{L}$ and $\alpha$ is greater than 0.24 , the permeation flux is greater than $22.5 \mathrm{~L} / \mathrm{m}^{2} \cdot \mathrm{h}$. Figure 6 shows that the interaction between the $\mathrm{Cd}^{2+}$ concentration and the $\mathrm{pH}(\mathrm{AC})$ is insignificant when $\alpha$ is kept at 0.175 ; the $\mathrm{pH}$ has a greater effect on the permeation flux than the $\mathrm{Cd}^{2+}$ concentration does, and the permeation flux increases with the $\mathrm{pH}$. Figure 7 shows that the interaction between $\alpha$ and the $\mathrm{pH}(\mathrm{BC})$ is significant when the $\mathrm{Cd}^{2+}$ concentration is kept at $25 \mathrm{mg} / \mathrm{L} ; \alpha$ has a smaller effect on the permeation flux than the $\mathrm{pH}$ does, and $\mathrm{J}$ is greater than $20 \mathrm{~L} / \mathrm{m}^{2} \cdot \mathrm{h}$ when the $\mathrm{pH}$ is above 8.6. 
Table 7. Tests for the response function, J.

\begin{tabular}{ccccccc}
\hline Source & df & SS & MS & F-Value & $\boldsymbol{P}$ & Significant \\
\hline Model & 9 & 1299.65 & 144.405 & 113.57 & $<0.001$ & $* *$ \\
Linear & 3 & 1132.76 & 50.798 & 39.95 & 0.001 & $* *$ \\
Square & 3 & 133.40 & 44.465 & 34.97 & 0.001 & $* *$ \\
Interaction & 3 & 33.49 & 11.164 & 8.78 & 0.019 & $*$ \\
A & 1 & 15.12 & 5.272 & 4.15 & 0.097 & \\
B & 1 & 24.85 & 23.115 & 18.18 & 0.008 & $* *$ \\
C & 1 & 1092.78 & 92.741 & 72.94 & $<0.001$ & $* *$ \\
$\mathrm{~A}^{2}$ & 1 & 28.09 & 29.207 & 22.97 & 0.005 & $*$ \\
$\mathrm{~B}^{2}$ & 1 & 69.54 & 61.690 & 48.52 & 0.001 & $* *$ \\
$\mathrm{C}^{2}$ & 1 & 35.77 & 35.770 & 28.13 & 0.003 & $*$ \\
AB & 1 & 17.64 & 17.640 & 13.87 & 0.014 & $*$ \\
AC & 1 & 5.29 & 5.290 & 4.16 & 0.097 & \\
BC & 1 & 10.56 & 10.562 & 8.31 & 0.034 & $*$ \\
Residual & 5 & 6.36 & 1.271 & & & \\
Lack of fit & 3 & 6.12 & 2.039 & 16.99 & 0.056 & \\
Pure error & 2 & 0.24 & 0.120 & & & \\
Cor total & 14 & 1306.00 & & & & \\
$\mathrm{R}^{2}=0.995$ & & & & & &
\end{tabular}

Note: $P<0.05$ indicates that the item is significant and is denoted by "**, $P<0.01$ indicates that the item is extremely significant and is denoted by " ***”. A is the $\mathrm{Cd}^{2+}$ concentration; $\mathrm{B}$ is the ratio of the sophorolipid concentration to the total surfactant concentration $(\alpha) ; \mathrm{C}$ is the $\mathrm{pH} ; \mathrm{AC}$ represents the interaction of the $\mathrm{Cd}^{2+}$ concentration $(\mathrm{A})$ and the $\mathrm{pH}(\mathrm{C})$, and $\mathrm{AB}$ and $\mathrm{BC}$ are similarly defined; $\mathrm{A}^{2}$ is the quadratic term for the $\mathrm{Cd}^{2+}$ concentration $(\mathrm{A})$, and $\mathrm{B}^{2}$ and $\mathrm{C}^{2}$ are similarly defined.

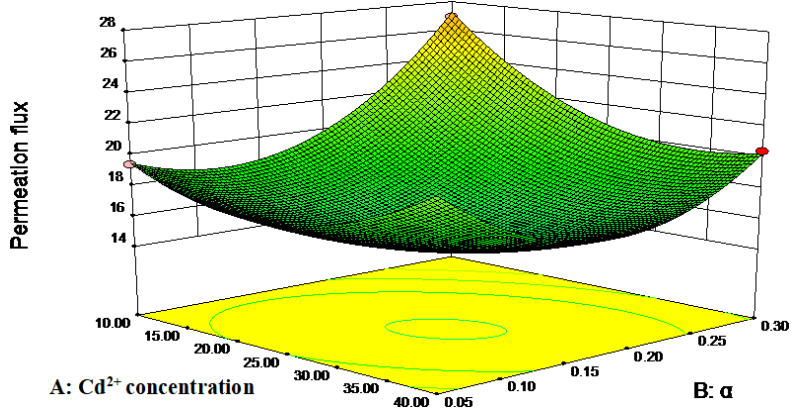

(a)

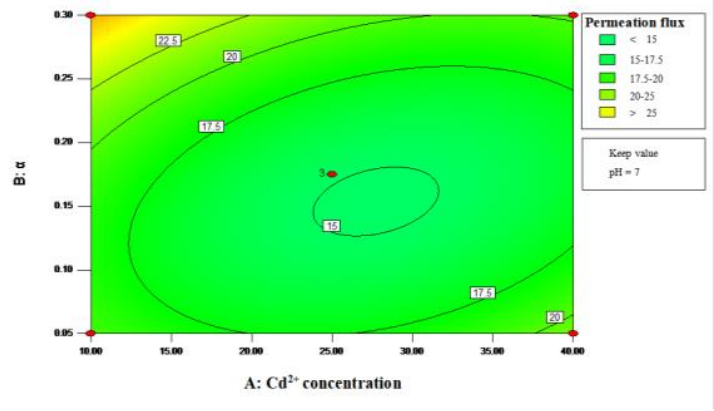

(b)

Figure 5. Response surface (a) and isolines (b) for the permeation flux, the $\mathrm{Cd}^{2+}$ concentration and $\alpha$.

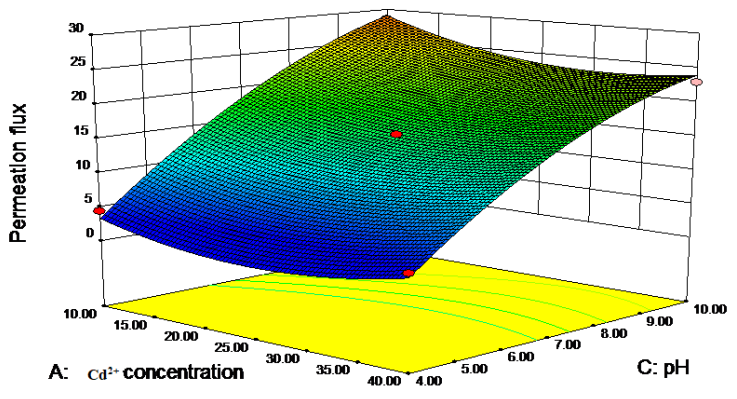

(a)

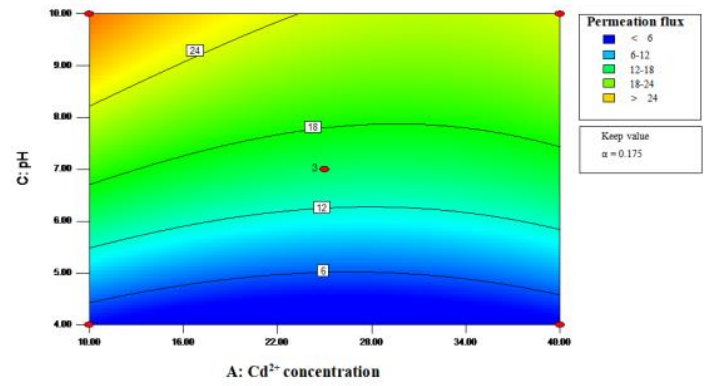

(b)

Figure 6. Response surface (a) and isolines (b) for the permeation flux, the $\mathrm{Cd}^{2+}$ concentration and the $\mathrm{pH}$. 


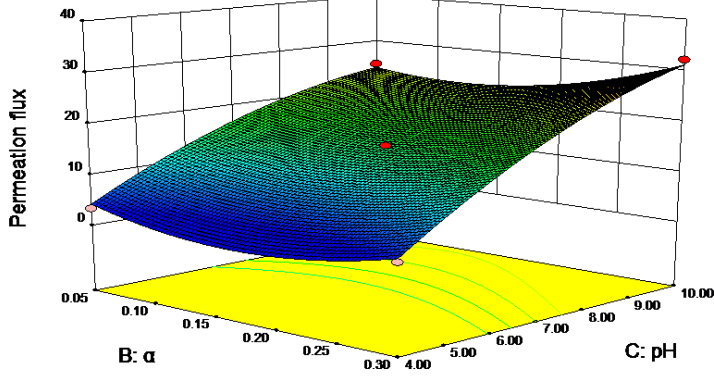

(a)

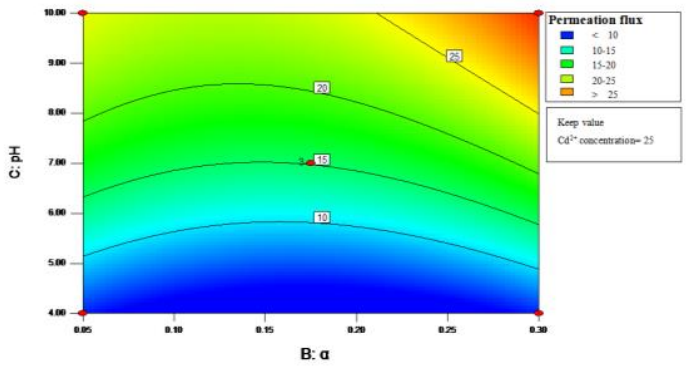

(b)

Figure 7. Response surface (a) and isolines (b) for the permeation flux, $\alpha$ and the $\mathrm{pH}$.

\subsection{Prediction and Validation of Optimum Filtration Conditions}

The response optimizer in Minitab 16 was used to examine the responses of the $\mathrm{Cd}^{2+}$ rejection coefficient and the permeation flux simultaneously. The weight and degree of importance of each index was set to 1 and the optimization results are shown in Table 8.

Table 8. Response to optimization results.

\begin{tabular}{ccccc}
\hline Optimization Condition & Response Project & Response Result & Desirability & $\begin{array}{c}\text { Optimized Composite } \\
\text { Desirability }\end{array}$ \\
\hline $\mathrm{Cd}^{2+}$ concentration $=10.0 \mathrm{mg} / \mathrm{L}$ & $\mathrm{Cd}^{2+}$ rejection rate & $99.14 \%$ & 1.00 & \\
$\mathrm{~A}=0.30$ & Permeation flux & $37.36 \mathrm{~L} / \mathrm{m}^{2} \cdot \mathrm{h}$ & 1.00 & 1.00 \\
$\mathrm{pH}=9.58$ & & & \\
\hline
\end{tabular}

Table 8 shows that when the $\mathrm{Cd}^{2+}$ concentration is $10.0 \mathrm{mg} / \mathrm{L}, \alpha$ is 0.30 and the $\mathrm{pH}$ is 9.58 , the $\mathrm{Cd}^{2+}$ rejection coefficient and the permeation flux are optimized simultaneously; the optimized composite desirability is 1.00 . To further validate the reliability of the model's predictions, the optimized operating conditions were used to conduct experiments. For convenience in actual operation, the $\mathrm{Cd}^{2+}$ concentration was set to $10.0 \mathrm{mg} / \mathrm{L}, \alpha$ was set to 0.30 , and the $\mathrm{pH}$ was set to $9.5 \mathrm{in}$ the experiments. The measured $\mathrm{Cd}^{2+}$ rejection coefficient and the permeation flux were $98.74 \%$ and $37.02 \mathrm{~L} / \mathrm{m}^{2} \cdot \mathrm{h}$, respectively. The relative error was no greater than $1 \%$, and the experimental values were close to the predicted values, which indicates that the optimization model used in the paper is very reliable.

\section{Conclusions}

This work uses a mixture of the environmentally friendly biosurfactants rhamnolipids and sophorolipids as a source of micelles and investigates their effect on the ultrafiltration of $\mathrm{Cd}$. Furthermore, this work optimizes the ultrafiltration conditions by using the Box-Behnken response surface, and provides theoretical support for using MEUF to treat heavy metal-containing wastewater when biosurfactants are used for micelle formation. The main conclusions are as follows:

(1) Interactions among the three factors (the initial $\mathrm{Cd}^{2+}$ concentration, the ratio of biosurfactants $(\alpha)$ and the $\mathrm{pH}$ ) affect the enhanced ultrafiltration of $\mathrm{Cd}^{2+}$, and the significance of their effects on the rejection coefficient follows the order $\alpha<\mathrm{Cd}^{2+}$ concentration $<\mathrm{pH}$. The degree of impact on the permeation flux follows the order $\mathrm{Cd}^{2+}$ concentration $<\alpha<\mathrm{pH}$.

(2) The optimum $\mathrm{Cd}^{2+}$ removal conditions obtained from the experiments are as follows: $\mathrm{Cd}^{2+}$ concentration: $10.0 \mathrm{mg} / \mathrm{L} ; \alpha: 0.30$; and $\mathrm{pH}: 9.58$. Under these conditions, the $\mathrm{Cd}^{2+}$ rejection coefficient reaches $99.14 \%$, and the permeation flux reaches $37.36 \mathrm{~L} / \mathrm{m}^{2} \cdot \mathrm{h}$. The experimental results confirm that the experimental values agree well with the theoretically predicted values.

Author Contributions: T.C., H.F., and G.H. conceived and designed the experiments; T.C., H.Y., Z.Z., Y.W., and L.J. carried out the experiments; T.C., H.F., and M.X. analyzed the data; T.C. and H.F. wrote the main manuscript text and all authors reviewed the manuscript. 
Funding: This work was financially supported by the Fujian Science and Technology Guiding Project (2018Y0079), the National Natural Science Foundation of China (51109181), the Natural Science Foundation Project of Fujian Province (2018J01527) and the Supporting Plan for Excellent Talents in Colleges and Universities in the New Century of Fujian Province.

Conflicts of Interest: The authors declare no conflict of interest.

\section{References}

1. Tortora, F.; Innocenzi, V.; Prisciandaro, M.; Vegliò, F.; di Celso, G.M. Heavy Metal Removal from Liquid Wastes by Using Micellar-Enhanced Ultrafiltration. Water Air Soil Pollut. 2016, 227, 1-11. [CrossRef]

2. Rzętała, M.A. Cadmium contamination of sediments in the water reservoirs in Silesian Upland (southern Poland). J. Soils Sediments 2016, 16, 2458-2470. [CrossRef]

3. García-Alix, A.; Jimenez-Espejo, F.J.; Lozano, J.A.; Jiménez-Moreno, G.; Martinez-Ruiz, F. Anthropogenic impact and lead pollution throughout the Holocene in Southern Iberia. Sci. Total Environ. 2013, 449, 451-460. [CrossRef] [PubMed]

4. Liao, J.; Chen, J.; Ru, X.; Chen, J.; Wu, H.; Wei, C. Heavy metals in river surface sediments affected with multiple pollution sources, South China: Distribution, enrichment and source apportionment. J. Geochem. Explor. 2016, 176, 9-19. [CrossRef]

5. Sánchez-Chardi, A. Biomonitoring potential of five sympatric tillandsia, species for evaluating urban metal pollution (cd, hg and pb). Atmos. Environ. 2016, 131, 352-359. [CrossRef]

6. Hua, M.; Zhang, S.; Pan, B.; Zhang, W.; Lv, L.; Zhang, Q. Heavy metal removal from water/wastewater by nanosized metal oxides: A review. J. Hazard. Mater. 2012, 211-212, 317-331. [CrossRef] [PubMed]

7. Savic, I.M.; Stojiljkovic, S.T.; Gajic, D.G. Modeling and optimization of energy-efficient procedures for removing lead(II) and zinc(II) ions from aqueous solutions using the central composite design. Energy 2014, 77, 66-72. [CrossRef]

8. Qiu, W.; Zheng, Y. Removal of lead, copper, nickel, cobalt, and zinc from water by a cancrinite-type zeolite synthesized from fly ash. Chem. Eng. J. 2009, 145, 483-488. [CrossRef]

9. Tao, H.C.; Zhang, H.R.; Li, J.B.; Ding, W.Y. Biomass based activated carbon obtained from sludge and sugarcane bagasse for removing lead ion from wastewater. Bioresour. Technol. 2015, 192, 611-617. [CrossRef] [PubMed]

10. $\mathrm{Xu}, \mathrm{X}$.; Cao, X.; Zhao, L. Comparison of rice husk- and dairy manure-derived biochars for simultaneously removing heavy metals from aqueous solutions: Role of mineral components in biochars. Chemosphere 2013, 92, 955-961. [CrossRef] [PubMed]

11. Ronda, A.; Calero, M.; Blázquez, G.; Pérez, A.; Martín-Lara, M.A. Optimization of the use of a biosorbent to remove heavy metals: Regeneration and reuse of exhausted biosorbent. J. Taiwan Inst. Chem. Eng. 2015, 51, 109-118. [CrossRef]

12. Wang, J.; Chen, C. The current status of heavy metal pollution and treatment technology development in china. Environ. Technol. Rev. 2015, 4, 39-53. [CrossRef]

13. Burakov, A.E.; Galunin, E.V.; Burakova, I.V.; Kucherova, I.E. Adsorption of heavy metals on conventional and nanostructured materials for wastewater treatment purposes: A review. Ecotoxicol. Environ. Saf. 2017, 148, 702. [CrossRef] [PubMed]

14. Zhong, Y.J.; You, S.J.; Wang, X.H.; Zhou, X.; Gan, Y.; Ren, N.Q. Synthesis of carbonaceous nanowire membrane for removing heavy metal ions and high water flux. Chem. Eng. J. 2013, 226, 217-226. [CrossRef]

15. Wang, R.; Guan, S.; Sato, A.; Wang, X.; Wang, Z.; Yang, R. Nanofibrous microfiltration membranes capable of removing bacteria, viruses and heavy metal ions. J. Membr. Sci. 2013, 446, 376-382. [CrossRef]

16. Lu, J.; Li, Y.; Yin, M.; Ma, X.; Lin, S. Removing heavy metal ions with continuous aluminum electrocoagulation: A study on back mixing and utilization rate of electro-generated al ions. Chem. Eng. J. 2015, 267, 86-92. [CrossRef]

17. Al-Shannag, M.; Al-Qodah, Z.; Bani-Melhem, K.; Qtaishat, M.R.; Alkasrawi, M. Heavy metal ions removal from metal plating wastewater using electrocoagulation: Kinetic study and process performance. Chem. Eng. J. 2015, 260, 749-756. [CrossRef] 
18. Mitomo, S.K.; Nakahara, M.; Saeki, R.; Murakami, I. Recovery of heavy metals separated from high concentration wastewater by new sulfide precipitation system. J. Surf. Finish. Soc. Jpn. 2014, 65, 528-530. [CrossRef]

19. Salehi, R.; Mousavi, S.M.; Taherian, M. Assessment of micellar-enhanced ultrafiltration process performance for removal of pharmaceutical contaminant from wastewater using response surface methodology. Int. J. Environ. Sci. Technol. 2018. [CrossRef]

20. Fu, H.Y.; Zhang, Z.B.; Chai, T.; Huang, G.H.; Yu, S.J.; Liu, Z. Study of the removal of aniline from wastewater via meuf using mixed surfactants. Water 2017, 9, 365. [CrossRef]

21. Tanhaei, B.; Chenar, M.P.; Saghatoleslami, N.; Hesampour, M.; Kallioinen, M.; Sillanpää, M. Removal of nickel ions from aqueous solution by micellar-enhanced ultrafiltration, using mixed anionic-non-ionic surfactants. Sep. Purif. Technol. 2014, 138, 169-176. [CrossRef]

22. Chavan, M. Mathematical modelling for removal of mixture of heavy metal ions from waste-water using micellar enhanced ultrafiltration (meuf) process. Sep. Sci. Technol. 2015, 50, 365-372.

23. Schwarze, M.; Groß, M.; Moritz, M.; Buchner, G.; Kapitzki, L.; Chiappisi, L.; Gradzielski, M. Micellar enhanced ultrafiltration (meuf) of metal cations with oleylethoxycarboxylate. J. Membr. Sci. 2015, 478, 140-147. [CrossRef]

24. Liu, Z.; Yu, M.; Zeng, G.; Li, M.; Zhang, J.; Zhong, H.; Liu, Y.; Shao, B.; Li, Z.; Wang, Z.; et al. Investigation on the reaction of phenolic pollutions to mono-rhamnolipid micelles using MEUF. Environ. Sci. Pollut. Res. 2017, 24, 1230-1240. [CrossRef] [PubMed]

25. Pham, T.D.; Nguyen, N.K. Small Box-Behnken designs with orthogonal blocks. Stat. Probab. Lett. 2014, 85, 84-90. [CrossRef]

(c) 2019 by the authors. Licensee MDPI, Basel, Switzerland. This article is an open access article distributed under the terms and conditions of the Creative Commons Attribution (CC BY) license (http://creativecommons.org/licenses/by/4.0/). 